Vol. 8, Issue 10, October 2021

DOI: 10.17148/IARJSET.2021.81011

\title{
Impact on Taxation in Indian Consumer Goods Sectors during Covid-19
}

\author{
Pooja Jain $^{1}$, Dr Keerti Jain ${ }^{2}$ \\ ${ }^{1}$ Research Scholar, School of Management, GD Goenka University, Gurugram, Haryana, India. \\ ${ }^{2}$ Assistant Professor, Management Area, NIIT University, NH-8, Neemrana (Alwar)Rajasthan-301705 (India).
}

\begin{abstract}
Corona viruses are a large family of viruses which may cause illness in animals or humans. In humans, several corona viruses are known to cause respiratory infections ranging from the common cold. The economic impact of the 2020 corona virus pandemic in India has been largely disruptive. India's growth in the fourth quarter of the fiscal year 2020 went down to $3.1 \%$ according to the Statistics. Total Net Sales, Gross Profit, Net profit after tax and corporate tax are the main factors, which determined the financial status of any organization. In this adverse situation, graph of some sectors has fluctuated at compassion of normal situation. The main sector is Consumer Goods.

The Covid-19 is an unexpected event in the world history with substantial social-economic impact on the global economy. The global financial market was also badly affected as reflected by the extreme volatility as well as weak performances in financial of all over the world. The objective of this study is to identify the impact of the Covid-19 pandemic on the financial of Indian Consumer Goods Sectors. The study is based on the secondary data for the period of 8 years from the financial year 2013-2014 to 2020-21 of all the company's Consumer Goods of the Nifty 200.our sample size is 25 companies out of Nifty 200 .and these are related with Consumer Goods sectors to elaborate this study use the variable like Total Net Sales, Gross Profit, Net profit after tax and corporate tax.
\end{abstract}

Keywords: Consumer Goods, COVID- 19, Total Net Sales, Gross Profit, Net Profit After Tax, Corporate tax, Income Tax

\section{INTRODUCTION}

The functioning of a company in economic market depends on net sales, which predicts the effect on current decisions as well as future of the company. Task of managers mainly relies on managing and predicting future financial results. The best description of financial condition of a company is described by total net sales, net profit after tax and current corporate tax. As the purpose of financial planning is forecasting future economic plan of the company. These plans may encompass couple of periods, sometimes even many future years. Usually, it is assumed that company in future will work as effectively as it is working in the present condition. Sales revenues, net profit, and corporate tax (Income Tax) are terms that raise attention and questions to generate more interest to analysis the performance of the company from various angles, for the benefit of the company and beneficiaries to ensure the continuity of economic unity and achieving profits. Sales revenue is an item of the income statement. It is the total income that the entity receives as earning per share, and it is also the part of net profit, which is available for distribution to shareholder. The sales of company are categories into two types, i.e., sales of product and sales of service. The net revenue is the main figure in the financial statements, and it is the basis for many calculations and analyses. It is an important indicator of the performance and marketing ability to sell the product. Whereas profit is the income earned after the deduction of all expenses. It is always the goal of every enterprise. They are engaged in earning profit in different forms.

Gross profit is an Initial measurement of profitability that explained the revenue that exceeds the cost of goods sold (COGS). The gross profit show, how successful a company's executive management team is generating revenue, and considering the costs involved in producing their products and services. In Brief, the large the number in Gross Profit show, the more efficient management is in organization, and they are strong hand to generating profit for every rupee of cost involved in production.Net profit is a very important measurement of any entity to know the economy growth that expresses the amount a company earns per rupee of sales. If a company makes more money per sale, it has a higher profit. There are two main parts of profit i.e. Gross profit and net profit they used to assess a company's financial stability and overall health. The gross profit is the percentage of revenue that exceeds the COGS.A high gross profit indicates that a company is successfully producing profit over and above its costs.

Analysts are interested in profit after paying taxes, interest, and other expenses. There are two main types of profits that analysts have categorized, they are gross profit, and net profit. Both the types of profit give various information about the company's' performance. The profit levels of both the types can be taken from the income statement of the company. Corporate tax (income tax) is calculated based on net profit before tax. Net profit after tax drives after deducting the 


\section{International Advanced Research Journal in Science, Engineering and Technology}

Vol. 8, Issue 10, October 2021

\section{DOI: $10.17148 /$ IARJSET.2021.81011}

corporate tax (income tax) from the net profit before tax. Financial analysts often rely on net sales, net profit after tax and corporate tax.

The aim of the current study is to demonstrate the relationship between total net sales and net profit after tax and corporate tax of the Consumer Goods companies listed in Nifty200. The data is collected from financial year 2013-14 to 2020-21, i.e., pre-Covid -19 and during Covid-19 financial years. Also, an attempt is made to develop two regression model. For first regression model, total net sales are considered as independent variable and net profit after tax as dependent variables. For second model, net profit after tax is considered as independent variable and corporate tax as dependent variables. These regression models can be further used for predicting the value of net profit after tax and corporate tax.

\section{REVIEW OF LITERATURE:}

Ajanthan, (2013) explained that the goal of the companies is to minimize the cost of production at highest possibility of sales, in addition to future economy growth, it can progress ahead in competitive market. Sales are products received by customer from the sales department of companies. The sale of more products and services means that the company is in way of success and progress and enhances the wealth of the shareholders. AlQashi and Al-Oqlah, (2015) has conduct in their research that the sales are root of cash inflows in organisation, its helps to grow the assets of the accounting unit or it discharge the liability, which have been created through production, delivery of goods, provision of services or any other economic activity. It is principal factor of operations of the unit during a particular period, the measurement of expenses is based on sales in particular accounting period. In their study, Ball et al., (2016) analysed the main task of company is to do the manufacturing and delivery of the product and after that its desires to sale the largest quantity of product, so that it can capture the market of product and survive in competitive market of product. Capturing of market is based on quality of product \& public response of product. the study of Foerster et al. (2016), In any organisation, the cost of goods sold consists of the cost of finished production and is calculated by adding the cost of finished production at beginning to the total cost of production to reach the cost of the goods available for sale. The at end manufacturing includes costs associated with Production Costs of materials, wages, and indirect industrial expenses. These must be charged to the producing units because they have expected future benefits to be incurred during the current period and to be loaded on other units of the period that will be available in the coming period. This cost is considered as a product cost and is described as storage costs. In Nigeria, Government's taxation policy is based on a three-tier that are Federal, States and Local Governments having different tax jurisdiction, the most buoyant tax handles (taxes with higher rates and wider base) being under the control of the Federal government. The Federal Inland Revenue Service (FIRS) is the tax operative arm of the Federal Government in Nigeria which is responsible for taxation as enshrined in the exclusive legislative list under item 58 of the Second Schedules of 1999 constitution, as amended Ola (1999). Its duties are to assess, collect and account for federally collected taxes such as, Company Income Tax (CIT), Capital Gains Tax (CGT), Valued Added Tax (VAT), Petroleum Profit Tax (PPT), With-holding Tax (WT) and Stamp Duties base on stipulated rates approved by government. As per Nigeria's FIRS (2002), "in 2002 about forty different tax handles and levies were distributed amongst the three levels of Government. Amongst these, the Federal Government controlled higher rate and wider base taxes". As per the research of FIRS (2002), tax rate is a main variable to measuring the quantum of government earning by tax revenue within a specified period. Tax rate is therefore important and necessary for getting the quantum of tax revenue in hand of the Government. It is very crucial to know the compulsory contribution charged upon persons, properties, and businesses by relevant authorities for the support of Government. Also, it is important not only of tax revenue generation and provision of social and economic obligations of Government but also for equitable distribution of the tax burden, but also for the success of the company. That is, everyone is made to pay his "fair" part of his earning. According to Akabom and Effiong (2010), the total tax revenue generated from levies by the three tiers of Government in Nigeria, averaged 96.4 per cent for the Federal Government, 3.2 per cent for the States and 0.4 per cent for the Local Governments. Adesina (2006) found that, Nigeria regrets that it generates the tax revenue, which is even lesser than many countries like, Morocco, Kenya and India's tax revenue. However, the duty to account for taxes is beyond the scope of this study, while those of assessments and revenue collections based on government approved tax rates are of specific interest to this study. Peacock (1971) studied that the effect of fiscal policy on the financial variables such as income, output, employment, growth, prices, balance of payment and fiscal policy of any country, can influence the economic, political, social, cultural, and technological characteristics of the society concerned. Their arguments were on the assumption that government fiscal measures, such as taxation and government spending have important relationship to the movement of these financial variables and hence in the control of the economy. Kaldor (1963), analysis in his study, taxation is a sensitive matter capable of causing disorder and it is an area where the political leadership must treat with caution. Taxation which is supposed to be perceived as a civil obligation is not perceived as such but rather as an unnecessary burden. In examining the various aspects of tax policies as they affect economic development the emphasis has always been given on the tax base of these countries, which has to be broadened in order to raise tax revenue for development. In the study of Brennan and Buchanan (1977), the Laffer curve analysis correlates tax rates with tax revenue and the result shows that the higher tax rate is less likely the optimum tax revenue, while a lower tax rate may reasonably generate more tax revenues. Ghaus 


\section{International Advanced Research Journal in Science, Engineering and Technology}

Vol. 8, Issue 10, October 2021

\section{DOI: $10.17148 /$ IARJSET.2021.81011}

(1995) analysed that a Laffer curve give the actual position of the optimal tax rate and provides maximum tax revenue with evidential convictions to either increase or reduce tax rates depending on the direction of tax policy objectives. Gangadhar (1982), explained, the profitability Analysis of large public limited cement companies in India. V. K. Purohit (1982) analysis, the profitability trends of manufacturing industries in Indian corporate sector during 1950-51 to 197071. Sindhu Rani (1998) explained, the factors affecting profitability in Indian textile industry. Md. Rafiqul Islam (2000) examined, a study on the profitability of Fertilizer Industry in Bangladesh from 1985-86 to 1994-95. Manorselvi and Vijayakumar (2007) explained the trends in of profits of the selected Indian automobile companies during the period 1991-92 to 2003-04. Jordan et al. (2007) analysed the "An Analysis of the Comparative Predictive Abilities of Operating Cash Flows, Earnings, and Sales" and the sample size of his research work were 100 companies of the Fortune 1000 companies. Variable of his study were operating cash flows, earnings, and net sales for the years 2002 and 2003 .The study showed that the operating cash flows provided the weakest explanatory power; both the earnings and sales models produced statistically significant results. Martani et al. (2009) had done research on the effect of financial ratios, firm size, and cash flow from operating activities in the interim report to the stock return, the study uses profitability, liquidity, leverage, market ratio, size, and cash flow as proxies of accounting information. The samples of the study are in listed companies in man factoring industries that actively trading between 2003-2006 in Indonesia Stock Market. The result of this study was profitability, turnover and market ratio has significant impact to the stock return.

\section{OBJECTIVES OF THE STUDY}

i.The objective of the study are as follows:

ii.To explore gross profit, net profit after tax, corporate tax and total net sales of the Consumer Goods companies listed in Nifty 200 from 2013-14 to 2020-21.

iii.To identify the relationship between net profit after tax and total net sales of the Consumer Goods companies listed in Nifty 200 from 2013-14 to 2020-21.

iv.To identify the relationship between gross profit and corporate tax of the Consumer Goods companies listed in Nifty 200 from 2013-14 to 2020-21.

v.To develop a regression model of net profit after tax on total net sale of the Consumer Goods companies listed in Nifty 200.

vi.To develop a regression model of corporate tax on gross profit of the Consumer Goods companies listed in Nifty 2000.

\section{HYPOTHESIS OF THE STUDY}

The study has been taken up for the financial year 2013-2014 to 2020-2021, to test the following hypothesis:

i.There is significant correlation between total net sale and net profit after tax over the tenure for Consumer Goods sector companies listed in Nifty 200.

ii.There is significant correlation between gross profit and corporate tax over the tenure for the Consumer Goods companies listed in Nifty 200.

iii.The regression model developed for net profit after tax on total net sale of the Consumer Goods companies listed in Nifty 200 is significant.

iv.The regression model developed for corporate tax on Gross profit of the Consumer Goods companies listed in Nifty 2000 is significant.

\section{RESEARCH METHODOLOGY}

\subsection{Data Source}

There are 18 sectors in the Nifty 200 but for the study the 25 companies of Consumer Goods sector, which are listed in NIFTY 200 had been considered. The secondary data had been collected from "moneycontrol.com" for the financial year 2013-14 to 2020-21. Table is the list of companies under study.

Table 1: List of consumer goods Companies listed in Nifty 200

\begin{tabular}{|l|l|l|l|}
\hline S.No. & Name of the Company & S.No. & Name of the Company \\
\hline 1 & Aditya Birla Fashion and Retail Ltd. & 14 & Godrej Industries Ltd. \\
\hline 2 & Asian Paints Ltd. & 15 & Havells India Ltd. \\
\hline 3 & Avenue Supermarts Ltd. & 16 & Hindustan Unilever Ltd. \\
\hline 4 & Bata India Ltd. & 17 & ITC Ltd. \\
\hline 5 & Berger Paints India Ltd. & 18 & Jubilant Foodworks Ltd. \\
\hline 6 & Britannia Industries Ltd. & 19 & Marico Ltd. \\
\hline
\end{tabular}


International Advanced Research Journal in Science, Engineering and Technology

Vol. 8, Issue 10, October 2021

DOI: 10.17148/IARJSET.2021.81011

\begin{tabular}{|l|l|l|l|}
\hline 7 & Colgate Palmolive (India) Ltd. & 20 & PC Jeweller Ltd. \\
\hline 8 & $\begin{array}{l}\text { Crompton Greaves Consumer } \\
\text { Electricals Ltd. }\end{array}$ & $\begin{array}{l}\text { Procter \& Gamble Hygiene \& Health Care } \\
\text { Ltd. }\end{array}$ \\
\hline 9 & Dabur India Ltd. & 22 & Rajesh Exports Ltd. \\
\hline 10 & Emami Ltd. & 23 & Tata Global Beverages Ltd. \\
\hline 11 & Future Consumer Ltd. & 24 & United Breweries Ltd. \\
\hline 12 & Godrej Agrovet Ltd. & 25 & United Spirits Ltd. \\
\hline 13 & Godrej Consumer Products Ltd. & & \\
\hline
\end{tabular}

\subsection{Variables:}

In this research, three financial variables are considered for the study, viz, gross profit,net profit after tax, total net sales and corporate tax. For first regression model, total net sales are considered as independent variable and net profit after tax as dependent variables. For second model, gross profit is considered as independent variable and corporate tax as dependent variables. These regression models can be further used for predicting the value of net profit after tax and corporate tax. Following equations shows the calculation of the mentioned variables:

Total Net Sale = Revenue from Operations (Gross) - GST /Excise / Other levies + Other Income ... (5.1)

Gross Profit Total Net Sale - cost of goods Sold

NetProfitAfterTax $=$ NetProfitBeforeTax - Tax

Corporate Tax $=$ Current Year Income Tax of the Companies

\subsection{Statistical Tools and Techniques:}

Descriptive Statistics had been used to explore the four financial variables gross profit, net profit after tax, total net sales and corporate tax of Consumer Goods companies listed in Nifty 200. Correlation and Regression analysis has been conducted to examine the relationship between the variables and to impact of total net sales on net profit after tax and gross profit on corporate tax.

\section{RESULTS AND DISCUSSION}

Table 2: Year-wise Descriptive Statistics of the Consumer Goods Sector since 2013-14 to 2020-21

\begin{tabular}{|c|c|c|c|c|c|c|c|}
\hline Variables & Year & Mean & Median & Mode & $\begin{array}{l}\text { Std. } \\
\text { Deviation }\end{array}$ & Minimum & Maximum \\
\hline \multirow{8}{*}{$\frac{\overrightarrow{0}}{\stackrel{0}{0}}$} & $2020-21$ & 6281.20 & 3615.44 & NA & 8989.79 & 111.67 & 32406.90 \\
\hline & 2019-20 & 6388.96 & 3258.15 & NA & 8590.70 & 663.24 & 32674.28 \\
\hline & 2018-19 & 5956.08 & 3158.44 & NA & 7898.18 & 592.75 & 31990.82 \\
\hline & 2017-18 & 5198.50 & 2982.33 & NA & 6682.49 & 666.10 & 27829.48 \\
\hline & 2016-17 & 4685.59 & 2551.05 & NA & 6377.60 & 434.28 & 27678.95 \\
\hline & 2015-16 & 4354.36 & 2431.97 & NA & 5898.75 & 487.75 & 25724.47 \\
\hline & 2014-15 & 4021.88 & 2007.67 & NA & 5907.63 & 486.10 & 25734.10 \\
\hline & 2013-14 & 3521.60 & 1839.16 & NA & 5315.34 & 333.57 & 23103.73 \\
\hline \multirow{8}{*}{ 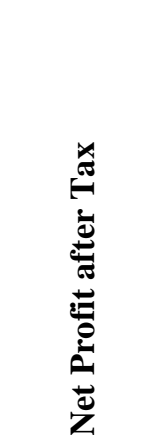 } & 2020-21 & 1422.64 & 605.00 & -650.00 & 2927.77 & -650.00 & 13032.00 \\
\hline & $2019-20$ & 1471.76 & 524.00 & -306.00 & 3155.04 & -306.00 & 15136.00 \\
\hline & 2018-19 & 1327.00 & 442.00 & -101.00 & 2611.89 & -101.00 & 12464.00 \\
\hline & 2017-18 & 1169.16 & 534.00 & 32.00 & 2326.96 & 32.00 & 11223.00 \\
\hline & 2016-17 & 1001.84 & 431.00 & -145.00 & 2117.44 & -145.00 & 10201.00 \\
\hline & 2015-16 & 947.80 & 401.00 & -104.00 & 2029.23 & -104.00 & 9845.00 \\
\hline & 2014-15 & 783.92 & 289.00 & -1956.00 & 2084.96 & -1956.00 & 9608.00 \\
\hline & 2013-14 & 583.08 & 277.00 & -5103.00 & 2176.06 & -5103.00 & 8785.00 \\
\hline
\end{tabular}


International Advanced Research Journal in Science, Engineering and Technology

Vol. 8, Issue 10, October 2021

DOI: 10.17148/IARJSET.2021.81011

\begin{tabular}{|c|c|c|c|c|c|c|c|}
\hline \multirow{8}{*}{ 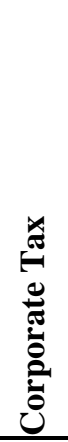 } & $2020-21$ & 448.88 & 176.00 & 0.00 & 905.19 & -56.00 & 4035.00 \\
\hline & 2019-20 & 447.68 & 176.00 & 0.00 & 943.63 & -1.00 & 4442.00 \\
\hline & 2018-19 & 564.76 & 250.00 & 0.00 & 1211.68 & 0.00 & 5849.00 \\
\hline & 2017-18 & 517.92 & 218.00 & 0.00 & 1143.53 & 0.00 & 5600.00 \\
\hline & 2016-17 & 447.40 & 154.00 & 0.00 & 1076.65 & 0.00 & 5286.00 \\
\hline & 2015-16 & 425.20 & 172.00 & 0.00 & 1010.31 & 0.00 & 4949.00 \\
\hline & 2014-15 & 358.88 & 128.00 & 0.00 & 851.87 & 0.00 & 4043.00 \\
\hline & 2013-14 & 316.16 & 129.00 & 0.00 & 796.36 & 0.00 & 3937.00 \\
\hline \multirow{8}{*}{ 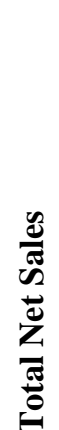 } & 2020-21 & 9822.76 & 5254.00 & 649.00 & 12562.87 & 649.00 & 48736.00 \\
\hline & 2019-20 & 11586.64 & 5843.00 & 2030.00 & 13603.54 & 2030.00 & 48633.00 \\
\hline & 2018-19 & 11088.84 & 6272.00 & 2186.00 & 12821.87 & 2186.00 & 47480.00 \\
\hline & $2017-18$ & 9654.20 & 5388.00 & 1992.00 & 11025.10 & 1992.00 & 42757.00 \\
\hline & 2016-17 & 9403.64 & 4812.00 & 1547.00 & 11988.09 & 1547.00 & 44991.00 \\
\hline & 2015-16 & 8641.16 & 5126.00 & 1338.00 & 10825.33 & 1338.00 & 38641.00 \\
\hline & 2014-15 & 7914.72 & 4487.00 & 0.00 & 10892.76 & 0.00 & 38051.00 \\
\hline & 2013-14 & 6663.44 & 3917.00 & 0.00 & 8847.30 & 0.00 & 34346.00 \\
\hline
\end{tabular}

From table 2 it is evident that the maximum mean of gross profit is ₹ 6388.96 in financial year 2020-21 with medium of $₹ 3258.15$ and standard deviation is ₹ 8590.70 in financial year 2020-21. Minimum Value of gross profit is ₹ $111.67 \&$ maximum value is ₹ 32406.90 in financial year 2020-21.

The total net sales are in financial year 2020-21 i.e., ₹ 48736.00 with mean of 9822.76 , Medium \& Mode is 5254.00 and 649.00 respectively, whenever standard deviation is 12562.87 in financial year 2020-21, but the maximum mean of total net sales is 11586.64 in financial year 2019-2020 and maximum medium of total net sales is 6272 in 2018-2019 and mode is 2186 also in financial year 2018-2019.on the other hand maximum standard deviation is 13603.54 in financial year also 2019-20.The total net sales are in financial year 2020-21 i.e., ₹ 48736.00 with mean of 9822.76 , Medium \& Mode is 5254.00 and 649.00 respectively, whenever standard deviation is 12562.87 in financial year 2020-21 but the maximum mean of total net sales is 11586.64 in financial year 2019-2020 and maximum medium of total net sales is 6272 in 2018 2019 and mode is 2186 also in financial year 2018-2019.on the other hand maximum standard deviation is 13603.54 in financial year also 2019-20.

Table 3: Correlation Table of Total Net Sales and Net Profit after Tax since 2013-14 to 2020-21

\begin{tabular}{|l|l|l|}
\hline Year & Correlation & p-value \\
\hline $2013-14$ & 0.672 & 0.000 \\
\hline $2014-15$ & 0.703 & 0.000 \\
\hline $2015-16$ & 0.728 & 0.000 \\
\hline $2016-17$ & 0.705 & 0.000 \\
\hline $2017-18$ & 0.798 & 0.000 \\
\hline $2018-19$ & 0.751 & 0.000 \\
\hline $2019-20$ & 0.724 & 0.000 \\
\hline $2020-21$ & 0.930 & 0.000 \\
\hline
\end{tabular}

From table 3, we can see that there is significantly strong positive correlation between Total Net Sales and Net Profit after Tax over the years. Since there is strong correlation between Total Net Sales and Net Profit after Tax, therefore a linear regression model has been developed, considering Total Net Sales as independent variable and Net profit after tax is as dependent variables. 
International Advanced Research Journal in Science, Engineering and Technology

Vol. 8, Issue 10, October 2021

DOI: 10.17148/IARJSET.2021.81011

Table 4: Regression Analysis of Net Profit after Tax on Total Net Sales

\begin{tabular}{|c|c|c|c|c|c|c|}
\hline Model & & Sum of Squares & df & Mean Square & $\mathbf{F}$ & p-value \\
\hline \multirow[t]{3}{*}{1} & Regression & 2193025.633 & 1 & 2193025.633 & 43.758 & 0.001 \\
\hline & Residual & 300699.435 & 6 & 50116.572 & & \\
\hline & Total & 2493725.068 & 7 & & & \\
\hline
\end{tabular}

a. Dependent Variable: Net Profit after Tax b. Predictors: (Constant), Total Net Sales

From table 4 , it is found that p-value is less than 0.05 , therefore at $5 \%$ level of significance the regression model of Net profit after tax on Total Net Sales is significant. Table 5. Shows the summary of the regression model of Net profit after tax on Total Net Sales.

\begin{tabular}{|l|l|l|l|l|}
\hline \multicolumn{6}{|l|}{ Table 5: Model Summary (Net Profit after Tax on Total Net Sales) } \\
\hline Model & R & R Square & Adjusted R Square & $\begin{array}{l}\text { Std. Error of the } \\
\text { Estimate }\end{array}$ \\
\hline $\mathbf{1}$ & $0.938^{\text {a }}$ & 0.879 & 0.859 & 223.86731 \\
\hline a. Predictors: (Constant), TotalNet Sales
\end{tabular}

From table 5, it is found the R-square is 0.879 . Therefore, the variation in the value of Net Profit after tax is $87.9 \%$ explained by total net sales over the years. The proposed model is significantly showing the relation between net profit after tax and total net sales. The model can be used for the prediction of the net profit after tax value for future years.

From table 6, following regression equation of Net Profit after Tax on Total Net Sales has been obtained:

Net Profit After Tax $=0.362($ Total Net Sales) -1300.811

From table 7, we can see that there is significant strong positive correlation between Corporate Tax and Gross Profit over the years at 5\% level of significance. Since there is strong correlation between and Corporate Tax and Gross Profit, therefore a linear regression model has been developed, considering Gross Profit as independent variable and Corporate Tax is as dependent variables.

\begin{tabular}{|c|c|c|c|c|c|c|}
\hline \multirow{2}{*}{\multicolumn{2}{|c|}{ Model }} & Unstandar & Coefficients & $\begin{array}{l}\text { Standardized } \\
\text { Coefficients }\end{array}$ & \multirow[b]{2}{*}{$t$} & \multirow[b]{2}{*}{ Sig. } \\
\hline & & $\mathrm{B}$ & Std. Error & Beta & & \\
\hline \multirow[t]{2}{*}{1} & (Constant) & -1300.811 & 519.961 & & -2.502 & 0.046 \\
\hline & Total Net Sales & 0.362 & 0.055 & 0.938 & 6.615 & 0.001 \\
\hline
\end{tabular}

Table 7: Correlation Table of Corporate Tax and Gross Profit since 2013-14 to 2020-21

\begin{tabular}{|l|l|l|}
\hline Year & Correlation & p-value \\
\hline $2013-14$ & 0.933 & 0.000 \\
\hline $2014-15$ & 0.961 & 0.000 \\
\hline $2015-16$ & 0.923 & 0.000 \\
\hline $2016-17$ & 0.900 & 0.000 \\
\hline $2017-18$ & 0.877 & 0.000 \\
\hline $2018-19$ & 0.871 & 0.000 \\
\hline $2019-20$ & 0.846 & 0.000 \\
\hline $2020-21$ & 0.878 & 0.000 \\
\hline
\end{tabular}




\section{International Advanced Research Journal in Science, Engineering and Technology}

Vol. 8, Issue 10, October 2021

DOI: $10.17148 /$ IARJSET.2021.81011

Table 8: Regression Analysis of Corporate Tax on Gross Profit

\begin{tabular}{|l|l|l|l|l|l|l|}
\hline \multicolumn{9}{|c|}{} & Sum of Squares & df & Mean Square & F & Sig. \\
\hline Model & Regression & 74957.700 & 1 & 74957.700 & 5.885 & $0.051 \mathrm{~b}$ \\
\cline { 2 - 7 } & Residual & 76420.537 & 6 & 12736.756 & & \\
\cline { 2 - 7 } & Total & 151378.236 & 7 & & & \\
\hline
\end{tabular}

From table 8 , it is evident that p-value $(0.051)$ is greater than 0.05 , therefore at $5 \%$ level of significance the regression model of corporate tax on Gross Profit is not significant. Further table 9. shows the summary of the regression model of corporate tax on gross profit, it shows that R-square as 0.495 , which is very less, this implies only $49.5 \%$ of variation in the corporate tax is explained by Gross Profit. Therefore, the regression model is not feasible.

Table 9: Model Summary (Net Profit after Tax on Total Net Sales)

\begin{tabular}{|l|l|l|l|l|}
\hline Model & $R$ & R Square & $\begin{array}{l}\text { Adjusted } \\
\text { Square }\end{array}$ & $\begin{array}{l}\text { R Std. Error of the } \\
\text { Estimate }\end{array}$ \\
\hline 1 & $0.704^{\mathrm{a}}$ & 0.495 & 0.411 & 112.85724 \\
\hline
\end{tabular}

a. Predictors: (Constant), Gross Profit

\section{LIMITATIONS}

There are following limitation in this research paper:

- $\quad$ Data has been taken only of the companies listed in NIFTY 200.

- $\quad$ Only Consumer Goods sector has been included in the research work.

- Other financial as well as non-financial variable may have impact on current year tax \& net profit after tax.

- $\quad$ Data of this study is from 2013-14 to 2020-21(8 years).

\section{CONCLUSION}

Covid-19 pandemic had been started in last March 2021, it had changed the social life as well as economical life of Nation, it has dropped the effect on taxation as well as financial variable of the Nifty 200.This effect will be also seen in upcoming financial years. Due to the Covid-19's pandemic Indian Government has floated the lot of subsidy \& benefits to the industry to cope out from this pandemic. Present study is based on Nifty 200 companies for the financial year $2013-$ 14 to 2020-21, specially focused on Consumer Goods Sectors. This study analysed the impact on taxation of the financial variable related with Indian Consumer Goods sectors Pre-Covid-19 and during Covid-19 pandemic. It is found that the total net sales and net profit after tax are maximum for the finical year 2019-20. But the corporate tax is maximum in year 2018-19. There is significantly strong positive correlation between total net sales and net profit after tax and between gross profit and corporate tax at $5 \%$ level of significance. The only one regression models developed are significantly good enough at $5 \%$ level of significance for predicting net profit after tax for future years. But regression models of corporate tax are not feasible.

\section{REFERENCES}

1. Adesina, G. O. (2006). Tax reforms: The journey so far. Paper presented at a workshop organized by Federal Inland Revenue Service, Lokoja, April 13-14.

2. Ajanthan, A. (2013). The relationship between dividend payout and firm profitability: A study of listed hotels and restaurant companies in Sri Lanka. International Journal of Scientific and Research Publications, 3(6), 1-6.

3. Akabom, A. I. and Effiong, S. A. (2010). Tax management as an alternative tool for economic recovery and development in cross river state; International Journal of Accounting: 2 (1), $38-44$.

4. Al-Qashi, Z. S., \& Al-Aqlah, M. (2015) The Impact of Compliance of Revenue Recognition Principle on the Problems of Income Resources in Arab Satellite Channel Measuring. Algerian Journal of Accounting and Financial Studies Issue 1, 2015.

5. Ball, R., Gerakos, J., Linnainmaa, J. T., \& Nikolaev, V. (2016). Accruals, cash flows, and operating profitability in the cross section of stock returns. Journal of Financial Economics, 121(1), 28-45.

6. Brennan, G. and Buchanan, J. (1977). Towards a tax constitution for Leviathan. Journal of Public Economics. 8(2), 255-27

7. Foerster, S., Tsagarelis, J., \& Wang, G. (2016). Are Cash Flows Better Stock Return Predictors Than Profits? Financial Analysts Journal, 73(1), 73-99.

8. Federal Republic of Nigeria (1999). 1999 constitution of the Federal Republic of Nigeria. Lagos: Government Press. 


\title{
International Advanced Research Journal in Science, Engineering and Technology
}

\author{
Vol. 8, Issue 10, October 2021
}

\section{DOI: 10.17148/IARJSET.2021.81011}

9. Federal Inland Revenue Service (2002). General tax guide for tax administrators and practitioners. Abuja: Federal Inland Revenue Service. 10. Federal Republic of Nigeria (2002). Personal income tax act 1993: 1993 No.104: Operation of pay as you earn (PAYE) regulation s 2002. Abuja: Federal Ministry of Finance.

11. Gangadhar, -Cement Industry-Some aspects of Profitabilityll, The Management Accountant, Vol.4, No.2, 1982

12. Ghaus, A. (1995). Optimal local sales tax. Urban Studies, 32, 1361-1381.

13. Jordan, C. E., Waldron, M. A., \& Clark, S. J. (2007). An analysis of the comparative predictive abilities of operating cash flows, earnings, and sales. Journal of Applied Business Research, 23(3), 53.

14. Kaldor, N. (1963). Taxation for economic development. Journal of Modern African Studies, 1 (1), $234-242$.

15. . Martani, D., Khairurizka, R., \& Khairurizka, R. (2009). The effect of financial ratios, firm size, and cash flow from operating activities in the interim report to the stock return. Chinese Business Review, 8(6), 44-55.

16. Mohammed RafiqulIslam, - Profitability of Fertilizer Industry in Bangladeshll, The Management Accountant, 2000, pp.338-345.

17. Peacock, A. (1971). The economic theory of fiscal policy. London: George Allen \& Unwin.

18. Vishnu Kanta Purohit, -Profitability in Corporate Sectorll, ArthaVijnana, Vol.24, No.1, 1982, pp.50-66.

19. H S SindhuRani, -Factors affecting profitability in Indian Textile Industryll, The Indian Economic Journal, Vol.1, No.3, 1998, pp.137-143.

20. Manor Selvi and Vijayakumar, - Structure of Profits Rates in Indian Automobile Industries-A Comparisonll, The Management Accountant, Vol.42, No.10, 2007, pp.784-789 